\title{
PERFORMANCE OF DIHAPLOID WHEAT LINES OBTAINED VIA ANTHER CULTURE
}

\author{
Marcus Vinicius Salomon ${ }^{1,5}$; Carlos Eduardo de Oliveira Camargo ${ }^{1,2 *}$; Armando Petinelli Jr. ${ }^{3}$; \\ Joaquim Adelino de Azevedo Filho ${ }^{4}$ \\ ${ }^{1}$ Depto. de Produção Vegetal - USP/ESALQ, C.P. 9 - CEP: 13418-900 - Piracicaba, SP. \\ ${ }^{2}$ Centro de Análise e Pesquisa Tecnológica do Agronegócio dos Grãos e Fibras - IAC, C.P. 28 - CEP: 13001-970 - \\ Campinas, $S P$. \\ ${ }^{3}$ Unidade de Pesquisa do Desenvolvimento de Tatuí - APTA \\ C.P. 33 - CEP: $18270-000$ - Tatuí, SP. \\ ${ }^{4}$ Polo Regional de Desenvolvimento Tecnológico dos Agronegócios Leste-Paulista APTA, C.P. 1 - CEP: 13910-000- \\ Monte Alegre do Sul, SP. \\ ${ }^{5}$ FAPESP Fellow. \\ ${ }^{\star}$ Corresponding author <ccamargo@iac.cec.br>
}

ABSTRACT: The anther culture technique has been used in breeding programs to obtain haploid plants from hybrid plants of $F_{1}$ generation and to develop more efficiently wheat cultivars. To study the behavior of dihaploid wheat lines and two check cultivars, IAC-24 and IAC-289, experiments were carried out under sprinkler irrigation at Monte Alegre do Sul, SP, Brazil, in an Haplic Acrisol and at Tatuí, SP, Brazil, in a Rhodic Ferrasol, during the years 1999 and 2000. Genotypes were evaluated for grain yield, 100 grain weight, plant height, resistance to leaf rust (Puccinia recondita f. sp. triticiRob. Desm.) and lodging. The genotypes were also evaluated under laboratory conditions for their $\mathrm{Al}^{+3}$ toxicity tolerance using nutrient solutions. The line 8 , originated from ANA/ IAC-24 cross, presented high grain yield, semidwarf plant type, heavy grain, leaf rust resistance and tolerance to $\mathrm{Al}^{+3}$ toxicity. The lines $4,11,12$ and 14 , also presented high tolerance to $\mathrm{Al}^{+3}$ toxicity in association to grain yield above $3.000 \mathrm{~kg} \mathrm{ha}^{-1}$. These lines are suitable to be used in breeding programs to develop cultivars for acid soils. Key words: grain yield, 100 grain weight, plant height, lodging, tolerance to aluminum

\section{DESEMPENHO DE LINHAGENS DIAPLÓIDES DE TRIGO OBTIDAS POR CULTURA DE ANTERAS}

\begin{abstract}
RESUMO: Visando aumentar a eficiência no desenvolvimento de novos cultivares de trigo, a técnica de cultura de anteras in vitro tem sido utilizada em programas de melhoramento para a obtenção de plantas haplóides a partir de plantas híbridas em geração $\mathrm{F}_{1}$. Estudou-se o comportamento de 18 linhagens diaplóides e dois cultivares controles, IAC-24 e IAC-289, em ensaios instalados em condição de irrigação por aspersão, em Monte Alegre do Sul num Argissolo Vermelho-Amarelo e em Tatuí num Latossolo Vermelho, nos anos de 1999 e 2000. Todos os genótipos foram avaliados quanto à produção de grãos, massa de cem grãos, altura de planta, resistência à ferrugem-da-folha ( Puccinia recondita f. sp. tritici Rob. Desm.) e porcentagem de acamamento. Foram avaliados, também, em relação a tolerância à toxicidade ao alumínio, em soluções nutritivas, em condição de laboratório. A linhagem 8 proveniente do cruzamento ANA/IAC-24, apresentou elevada produção de grãos, porte semi-anão, grãos pesados, resistência à ferrugem-da-folha e tolerância à toxicidade ao alumínio. As linhagens 4,11, 12 e 14, também mostraram elevada tolerância à toxicidade ao alumínio associada a produção de grãos superior a $3.000 \mathrm{~kg} \mathrm{ha}^{-1}$, e portanto poderiam ser utilizadas em programas de melhoramento visando a obtenção de cultivares para solos ácidos.

Palavras-chave: produção de grãos, massa de cem grãos, altura de planta, acamamento, tolerância ao alumínio
\end{abstract}

\section{INTRODUCTION}

Brazil's wheat production was approximately 1.5 million tons in the 1999/2000 cropping season. With an estimated consumption of 9.7 million tons, the country had to import 7.5 million tons of grain wheat and 203 thousand tons of flour, which represented an expenditure of 902 million dollars (CONAB, 2001).

The decrease of the domestic wheat production is mainly due to political and climatic factors, and to those inherent to the adaptation of the crop itself, which have been rendering the country increasingly dependent upon imports in order to supply its domestic demand, and placing it on a prominent rank as a great importer (Tomasini, 1982).

With the objective of increasing the production of wheat in the State of São Paulo, Brazil, the genetic breeding program of Instituto Agronômico (IAC), in Campinas, has been directed toward obtaining cultivars with broad adaptability, semi-dwarf size, high productivity potential, and tolerance to aluminum toxicity, by means of crosses between domestic cultivars adapted to acid soil conditions, and cultivars of Mexican origin, with high productive potential and semi-dwarf size (Camargo et al., 1996). 
In order to increase the efficiency in obtaining wheat cultivars, the in vitro anther culture technique has been utilized in breeding programs to obtain haploid plants from hybrid plants in the $F_{1}$ generation. This technique speeds up the process of development of new cultivars by several years, in addition to simplifying and making the selection process more efficient (Moraes-Fernandes, 1997; Camargo et al., 1999; Ramos et al., 2000).

Through a preliminary evaluation, under field conditions, the dihaploid lines presented great variability of agronomic characters such as plant height, grain production, 100 grain weight, lodging and leaf rust resistance (Brammer et al., 1999), and had also differences in relation to their tolerance to aluminum toxicity, when evaluated in nutrient solution, in the laboratory (Camargo et al., 1999).

The objective of this paper was to assess dihaploid wheat lines, obtained through the in vitro anther culture technique, in order to identify genotypes having agronomically interesting traits for wheat breeding programs.

\section{MATERIAL AND METHODS}

An assay consisting of 18 dihaploid lines, obtained in 1998 at IAC, originated from anther cultures, and two control cultivars, IAC-24 and IAC-289 (Table 1), was installed under sprinkler irrigation conditions in Monte Alegre do Sul, SP, Brazil, (Wheat Production Zone H, latitude $22^{\circ} 41^{\prime} \mathrm{S}$, longitude $46^{\circ} 43^{\prime} \mathrm{W}$, altitude $777 \mathrm{~m}$ in a Haplic Acrisol) in May, and in Tatuí, SP, Brazil (Wheat Production Zone D, latitude $23^{\circ} 20^{\prime} \mathrm{S}$, longitude $47^{\circ} 52^{\prime}$ $\mathrm{W}$, altitude $600 \mathrm{~m}$ in a Rhodic Ferrasol), in April, during the years 1999 and 2000.

The control cultivars had the following traits: IAC24 - intermediate cycle, semi-dwarf size, tolerance to aluminum toxicity, good bread-making quality, medium soil fertility requirements, medium response to nitrogen fertilization, susceptible to the causal agent of leaf rust (Puccinia recondita f. sp. tritici Rob. Desm.) (IAC, 1996); IAC-289 - intermediate-to-late cycle, semi-dwarf size, medium tolerance to aluminum toxicity, good breadmaking quality, high soil fertility requirements, high response to nitrogen fertilization, sensitive to pre-harvest sprouting, susceptible to the causal agent of leaf rust (Felício et al., 1994).

Each trial was based on a random block statistical design, with four replicates. Each trial consisted of 80 plots, each plot formed by six rows $3 \mathrm{~m}$ long, spaced $0.20 \mathrm{~m}$. Sowing was performed at 80 viable seeds per linear meter of furrow, which is equivalent to 1,440 seeds per plot, consisting of $3.6 \mathrm{~m}^{2}$ of harvesting area.

Soil samples were taken from a 0-20 cm layer, and the corresponding chemical analyses can be found in Table 2. The amounts of fertilizers $\left(\mathrm{N}, \mathrm{P}_{2} \mathrm{O}_{5}\right.$ and $\left.\mathrm{K}_{2} \mathrm{O}\right)$ utilized in the two locations were based on the fertilizer recommendation tables of IAC in function of the soil chemical analyses (Raij et al., 1985).

Table 1 - Origins and genealogies of the genotypes assessed in the Dihaploid Wheat Lines Trial, at Polo Regional de Desenvolvimento Tecnológico dos Agronegócios Leste-Paulista, in Monte Alegre do Sul and at Unidade de Pesquisa do Desenvolvimento de Tatuí, during 1999 and 2000.

\begin{tabular}{crl}
\hline Genotype & \multicolumn{1}{c}{ Origin $^{1}$} & Genealogy \\
\hline 1 & 2634 & PF70402/ALD"S"//PAT72160/ALD"S"/3/PEW"S"/4/OPATA/5/IAC-60 \\
2 & 798 & ANA/IAC-24//IAC-24 \\
3 & 822 & ANA/IAC-24//IAC-24 \\
4 & 843 & ANA/IAC-24//IAC-24 \\
5 & 852 & ANA/IAC-24//IAC-24 \\
6 & 859 & ANA/IAC-24//IAC-24 \\
7 & 861 & ANA/IAC-24//IAC-24 \\
8 & 865 & ANA/IAC-24 \\
9 & 866 & ANA/IAC-24 \\
10 & 868 & ANA/IAC-24//IAC-24 \\
11 & 2480 & FURY-KEN/SLM//ALDAN/4/PAT10/ALD//PAT72300/3/PVN /5/IAC-24 \\
12 & 2574 & JUP/ZP//COC/3/PVN/4/GEN/5/IAC-24 \\
13 & 818 & ANA/IAC-24//IAC-24 \\
14 & 2483 & PF70402/ALD"S"//PAT72160/ALD"S"/3/PEW"S"/4/OPATA/5/IAC-60 \\
15 & 2554 & CS/A.CURV//GLEN/3/ALD/PVN/4/SUZ8/5/IAC-24 \\
16 & 2558 & TEPOCA/IAC-24 \\
17 & 2598 & PF70402/ALD"S"//PAT72160/ALD"S"/3/PEW"S"/4/OPATA/5/IAC-60 \\
18 & 795 & ANA/IAC-24//IAC-24 \\
19 & & IAS-51/IRN 597-70 (IAC-24) \\
20 & & KVZ/BUHO"S"//KAL/BLUEBIRD (IAC-289) \\
\hline
\end{tabular}

${ }^{1}$ Number of the plant obtained from anther culture. 
All genotypes were assessed in the trials with regard to grain yield, plant height, 100 grain weight and lodging, according to Camargo et al. (1999), and in relation to leaf rust, according to Schramm et al. (1974).

Daily minimum temperatures were monitored during the periods May to September, for 1999 and 2000.

With respect to grain yield, 100 grain weight and plant height data, individual analyses of variance were performed for each location and year, as well as a joint analysis for each location in the two-year period and a joint analysis involving the four experiments, where the significances of effects from genotypes, years and experiments, as well as the interactions genotype $x$ year and genotype $x$ experiment, were evaluated by the $F$ test at $5 \%$. The Tukey test at $5 \%$ was used for comparing genotype means in each location and year, the mean of two years at each location, and the mean of the four experiments.

Simple correlations between the traits under evaluation were performed with the means of the four trials, considered jointly for each genotype, in order to estimate the degrees of association between the assessed traits.

The genotypes were also evaluated for their tolerance to aluminum toxicity under laboratory conditions according to Camargo \& Oliveira (1981) and Camargo et al. (1998), using nutrient solutions with 0 , 2, 4, 6, 8 and $10 \mathrm{mg} \mathrm{L}^{-1} \mathrm{Al}^{3+}$. Each solution treatment consisted of five replicates. Cultivars Anahuac (sensitive) and $\mathrm{BH}-1146$ (tolerant) were used as controls for all aluminum concentrations. Data analysis considered the means for the central primary root length of ten seedlings of each genotype, for each replicate. Genotypes that presented root growth were considered tolerant, while those not presenting root growth were considered sensitive, after 72 hours in complete nutritive solution without aluminum, following exposure for 48 hours to the treatment solutions containing the five different aluminum concentrations.

Table 2 - Results of soil ${ }^{1}$ sample analyses for the $0-20 \mathrm{~cm}$ layer, of locations where the Dihaploid Wheat Lines Trials were installed, during 1999 and 2000.

\begin{tabular}{lrrrrr}
\hline \multirow{2}{*}{ Variable } & \multicolumn{2}{c}{$\begin{array}{c}\text { Monte Alegre } \\
\text { do Sul }\end{array}$} & & \multicolumn{2}{c}{ Tatuí } \\
\cline { 2 - 3 } \cline { 5 - 6 } & 1999 & 2000 & & 1999 & 2000 \\
\hline $\mathrm{M} . \mathrm{O} .\left(\mathrm{g} \mathrm{dm}^{-3}\right)$ & 14.0 & 20.0 & & 25.0 & 23.0 \\
$\mathrm{pH} \mathrm{CaCl}$ & 5.3 & 5.3 & & 4.6 & 5.0 \\
$\mathrm{P} \mathrm{resina}\left(\mathrm{mg} \mathrm{dm}^{-3}\right)$ & 10.0 & 40.0 & & 49.0 & 45.0 \\
$\mathrm{~K}\left(\mathrm{mmol}_{\mathrm{c}} \mathrm{dm}^{-3}\right)$ & 2.8 & 3.2 & & 7.2 & 5.2 \\
$\mathrm{Ca}\left(\mathrm{mmol}_{\mathrm{c}} \mathrm{dm}^{-3}\right)$ & 23.0 & 34.0 & & 47.0 & 41.0 \\
$\mathrm{Mg}\left(\mathrm{mmol}_{\mathrm{c}} \mathrm{dm}^{-3}\right)$ & 8.0 & 10.0 & & 13.0 & 12.0 \\
$\mathrm{H}^{+}+\mathrm{Al}^{-3}\left(\mathrm{mmol}_{\mathrm{c}} \mathrm{dm}^{-3}\right)$ & 25.0 & 28.0 & & 58.0 & 43.0 \\
S.B. $\left(\mathrm{mmol}_{\mathrm{c}} \mathrm{dm}^{-3}\right)$ & 33.8 & 47.2 & & 67.2 & 57.2 \\
$\mathrm{CTC}\left(\mathrm{mmol}_{c} \mathrm{dm}^{-3}\right)$ & 58.8 & 75.0 & & 125.2 & 100.1 \\
\hline V $(\%)$ & 57.0 & 63.0 & 53.0 & 58.0 \\
\hline
\end{tabular}

\section{RESULTS AND DISCUSSION}

In general, the grain yield, 100 grain weight, and plant height data obtained in the year 2000 were lower than those of 1999 , possibly due to frosts that occurred in the two locations (Table 3 ). The monthly minimum temperatures were lower than those recorded for the same period in the previous year, in both locations (Figure 1).

In Monte Alegre do Sul the lowest temperatures of July 2000 occurred during the nights of the 17th $\left(-0.6^{\circ} \mathrm{C}\right)$, 18th $\left(0.8^{\circ} \mathrm{C}\right), 19$ th $\left(0.0^{\circ} \mathrm{C}\right)$ and 21 st $\left(0.4^{\circ} \mathrm{C}\right)$ days. During the same period, in Tatuí, extremely low minimum temperatures were recorded at the meteorological station, indicating severe frosts in the region that even matched the historical record. During that period, frosts occurred during the nights of the 17th $\left(-1.4^{\circ} \mathrm{C}\right)$, 18th $\left(-1.2^{\circ} \mathrm{C}\right), 21$ st $\left(-2.0^{\circ} \mathrm{C}\right)$ and 22 nd $\left(-1.8^{\circ} \mathrm{C}\right)$. The minimum temperatures at laun surface in Tatuí, on the nights of the 17th and 18th of July, 2000, were around $-7.0^{\circ} \mathrm{C}$; these are temperatures that fatally affected several crops, especially wheat. Leaf temperatures below $-2.0^{\circ} \mathrm{C}$ would be enough to cause damage to wheat plants; this temperature would correspond to $2.0^{\circ} \mathrm{C}$ measured inside the thermometer shelter (Mota, 1982).

When the grain yield means are considered together for the trials installed in Monte Alegre do Sul and Tatuí, during the two years, the analysis of variance presented effects for genotypes, trials, and for the genotype $x$ trial interactions (Table 3 ). The genotype $x$ trial interactions for grain yield was also verified by Camargo et al. (1990), while studying wheat lines at the Vale do Paranapanema, and by Camargo et al. (1991),

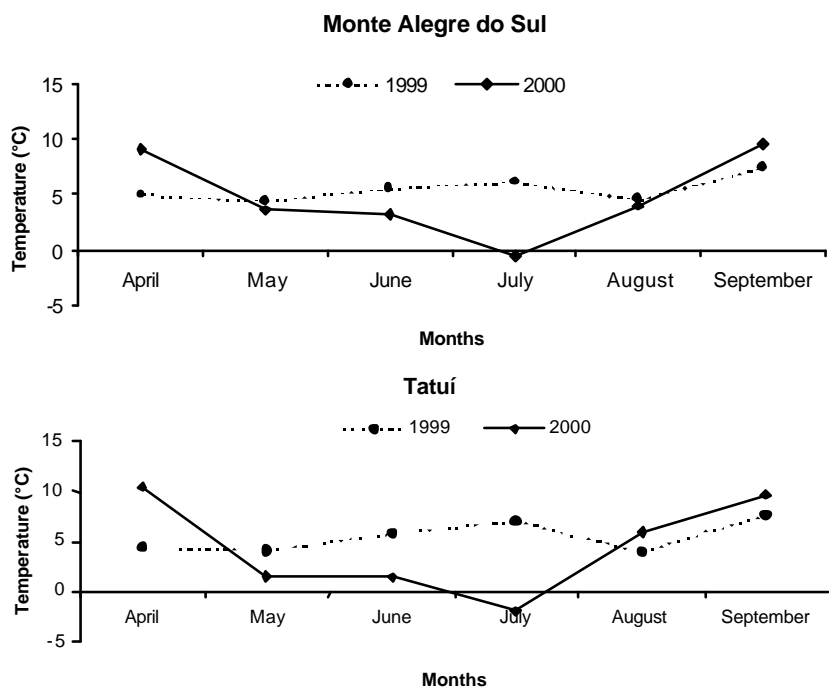

Figure 1 - Minimum temperature extremes from April through September, observed at Polo Regional de Desenvolvimento dos Agronegócios Leste-Paulista, in Monte Alegre do Sul and at Unidade de Pesquisa do Desenvolvimento de Tatuí, in 1999 and 2000. 
in an evaluation of genotypes from hybrid populations introduced from Oregon (USA) into the State of São Paulo. In spite of the genotype $x$ trial interaction, the cultivar IAC-289 and the line 8 were always among the most productive of the four trials, demonstrating that these genotypes had a good adaptability. In the comparison of means for grain yield of the four trials, genotypes $8\left(3,311 \mathrm{~kg} \mathrm{ha}^{-1}\right)$ and $20\left(3,341 \mathrm{~kg} \mathrm{ha}^{-1}\right)$ were the most productive, only being different in relation to lines $3\left(1,572 \mathrm{~kg} \mathrm{ha}^{-1}\right), 13\left(1,380 \mathrm{~kg} \mathrm{ha}^{-1}\right), 16(1,673 \mathrm{~kg}$ $\left.\mathrm{ha}^{-1}\right)$ and $18\left(1,852 \mathrm{~kg} \mathrm{ha}^{-1}\right)$.

In Monte Alegre do Sul, there was an effect on grain production only for genotypes and for years (Table $3)$. The non-significant interaction genotype $x$ year indicated that, despite of the difference between years, especially with regard to the low temperatures that occurred during the month of July, the most productive genotypes in 1999, had also a tendency to be the most productive in the following year. Genotype $20(4,165 \mathrm{~kg}$ $\left.\mathrm{ha}^{-1}\right)$ was the most productive, when the means of trials conducted in Monte Alegre do Sul are considered, in both years, only differing from genotypes $2,3,4,5,13,16$, 18 and 19.

The joint analysis of grain production data in Tatuí, for 1999 and 2000, presented significant effects for genotypes and for years, suggesting that the yield decrease in 2000 was due to environmental differences between the two years, especially the frosts of year 2000 . The interaction genotype $x$ year was also significant. When the grain yield means obtained in Tatuí are compared in terms of $\mathrm{kg} \mathrm{ha}^{-1}$, genotypes 1 (2,635), 2 (2,538), 4 (2,448), 8 (2,729), 19 $(2,680)$ and $20(2,517)$ were prominent, as they were different only from line 13 (521), the least productive. In 1999, line $1\left(3,896 \mathrm{~kg} \mathrm{ha}^{-1}\right)$ was the most productive, but it was not different, however, in $\mathrm{kg} \mathrm{ha}^{-1}$, from genotypes 2 $(3,055), 4(2,938), 7$ (3,048), $8(3,271), 9(2,917), 14(2,854)$, $17(2,868), 19(3,854)$ and $20(3,458)$. For the year 2000, line 8 was distinguished $\left(2,187 \mathrm{~kg} \mathrm{ha}^{-1}\right)$ as the most productive, being different, however, only from lines 10 $\left(1,285 \mathrm{~kg} \mathrm{ha}^{-1}\right)$ and $13\left(417 \mathrm{~kg} \mathrm{ha}^{-1}\right)$, the least productive.

Table 3 - Grain yield of genotypes assessed in the Dihaploid Wheat Lines Trial in Monte Alegre do Sul and in Tatuí, during 1999 and 2000.

\begin{tabular}{|c|c|c|c|c|c|c|c|}
\hline \multirow{2}{*}{ Genotype } & \multicolumn{3}{|c|}{ Monte Alegre do Sul } & \multicolumn{3}{|c|}{ Tatuí } & \multirow{2}{*}{$\begin{array}{c}\text { General } \\
\text { mean }\end{array}$} \\
\hline & 1999 & 2000 & Mean & 1999 & 2000 & Mean & \\
\hline & & & - & $\mathrm{g} \mathrm{ha}^{-1}--$ & & & \\
\hline 1 & $4143 a-d$ & 2038 a-d & 3090 a-d & $3896 a$ & $1375 a b$ & $2635 a$ & $2863 a-c$ \\
\hline 2 & $2861 d-g$ & $1247 \mathrm{de}$ & $2054 d-f$ & 3055 a-e & $2021 a b$ & $2538 a$ & 2296 a-d \\
\hline 3 & $1754 \mathrm{~g}$ & 688 e & $1221 \mathrm{f}$ & 2014 ef & $1834 a b$ & $1924 a b$ & $1572 \mathrm{~cd}$ \\
\hline 4 & $3552 b-f$ & $1403 c-e$ & $2477 c-f$ & $2938 a-e$ & $1958 a b$ & $2448 a$ & $2463 a-d$ \\
\hline 5 & $2535 \mathrm{e}-\mathrm{g}$ & $1691 \mathrm{c}-\mathrm{e}$ & $2113 c-f$ & $2327 c-f$ & $1702 a b$ & $2014 a b$ & $2063 a-d$ \\
\hline 6 & $4094 a-d$ & $2101 a-d$ & $3097 a-d$ & $2396 c-f$ & $1396 a b$ & $1896 a b$ & $2497 a-d$ \\
\hline 7 & $3983 a-e$ & $2639 a-c$ & $3311 a-c$ & $3048 a-e$ & $1570 a b$ & $2309 a b$ & $2810 a-c$ \\
\hline 8 & $4768 a b$ & $3017 a b$ & $3892 a b$ & $3271 \mathrm{a}-\mathrm{d}$ & $2187 \mathrm{a}$ & $2729 a$ & $3311 \mathrm{a}$ \\
\hline 9 & $4354 \mathrm{a}-\mathrm{c}$ & $2302 a-d$ & $3328 a-c$ & 2917 a-e & $1577 \mathrm{ab}$ & $2247 a b$ & $2787 a-c$ \\
\hline 10 & $3896 \mathrm{a}-\mathrm{f}$ & 2097 a-d & 2996 a-e & $2222 d-f$ & $1285 b$ & $1753 a b$ & $2375 a-d$ \\
\hline 11 & $4254 a-d$ & $2163 a-d$ & $3208 a-d$ & $2604 c-f$ & $1584 a b$ & $2094 a b$ & $2651 a-d$ \\
\hline 12 & $3955 a-e$ & $2639 a-c$ & 3297 a-c & $2729 b-f$ & $1465 a b$ & $2097 a b$ & 2697 a-d \\
\hline 13 & 2976 c-g & $1503 c-e$ & $2239 c-f$ & $625 \mathrm{~g}$ & $417 \mathrm{C}$ & $521 \mathrm{~b}$ & $1380 d$ \\
\hline 14 & $4604 a b$ & 3021 a & $3812 a b$ & 2854 a-e & $1861 \mathrm{ab}$ & $2358 a b$ & $3085 a b$ \\
\hline 15 & $3948 a-e$ & 1986 a-d & 2967 a-e & 2021 ef & $1535 a b$ & $1778 a b$ & $2372 a-d$ \\
\hline 16 & 2972 c-g & $635 \mathrm{e}$ & $1804 \mathrm{ef}$ & $1604 \mathrm{fg}$ & $1479 a b$ & $1542 a b$ & $1673 \mathrm{~cd}$ \\
\hline 17 & $4313 a-d$ & 2149 a-d & 3231 a-d & 2868 a-e & $1465 a b$ & $2167 a b$ & $2699 a-d$ \\
\hline 18 & $2462 \mathrm{fg}$ & $1056 \mathrm{de}$ & 1759 ef & 2097 ef & $1792 a b$ & $1944 a b$ & $1852 b-d$ \\
\hline 19 & $4042 a-d$ & $1726 b-e$ & $2884 \mathrm{~b}-\mathrm{e}$ & $3854 a b$ & $1507 a b$ & $2680 a$ & $2782 a-c$ \\
\hline 20 & 5288 a & $3042 \mathrm{a}$ & $4165 \mathrm{a}$ & $3458 a-c$ & $1577 a b$ & $2517 a$ & $3341 \mathrm{a}$ \\
\hline F (Gen.) & $9.89^{*}$ & $8.63^{*}$ & $12.91^{*}$ & $12.39^{*}$ & $5.42^{*}$ & $2.28^{*}$ & $4.34^{*}$ \\
\hline F (Years) & - & - & $339.73^{*}$ & - & - & $51.06^{*}$ & - \\
\hline F (Trials) & - & - & - & - & - & - & $65.18^{*}$ \\
\hline$F(G \times Y)$ & - & - & 1.27 & - & - & $6.04^{*}$ & - \\
\hline$F(G \times T)$ & - & - & - & - & - & - & $5.00^{*}$ \\
\hline d.m.s. ${ }^{(1)}$ & 1470 & 1292 & 1242 & 1149 & 813 & 1909 & 1369 \\
\hline C.V. (\%) & 14.98 & 25.14 & 19.06 & 16.57 & 19.62 & 18.11 & 18.93 \\
\hline
\end{tabular}

(1)Means followed by at least one common letter do not differ among themselves, by Tukey test.

*Significant at $5 \%$. 
The joint analysis of 100 grain weight in the trials installed in Monte Alegre do Sul and Tatuí, during the two years, presented significant effects for genotypes, for trials and for the genotype $x$ trial interactions, exhibiting a differential genotype behavior with regard to the environments (Table 4). This interaction could be explained by the fact that 100 grain weight is a trait controlled by several genes and has low heritability in crosses (Camargo, 1987a), thus being highly influenced by the environment. Despite of the significant interaction, line 8 yielded the heaviest grains, regardless of the environment. Significant effects were verified only for genotypes and years, when the trials in Monte Alegre do Sul were analyzed jointly, in 1999 and 2000 (Table 4). When the two-year mean is analyzed, line $8(4.32 \mathrm{~g})$ is prominent for its heavier grains, which were not different from lines 1, 7, 12, 14 and 15 and from cultivar IAC-289, which yielded 100 grain weight between 3.46 and $4.05 \mathrm{~g}$.
The joint analysis of data obtained in Tatuí, for both years, presented effects only for the genotype $x$ year interaction. For 1999, lines $8(4.51 \mathrm{~g})$ and $7(4.38 \mathrm{~g})$ were distinguished by their heavier grains, as they were not different only from lines $1,9,10$ and 12 , with 100 grain weight between 3.8 and $4.18 \mathrm{~g}$, and from cultivars IAC24 (3.96 g) and IAC-289 (3.89 g). For 2000, line 8 (4.76 g) exhibited the highest 100 grain weight, but it was not different from lines $3,11,14,15$ and 18 . Line 8 had the heaviest grains and line $13(2.07 \mathrm{~g})$, was the lightest during the two years, despite the significant interaction, considering the Tatuí trials jointly in 1999 and 2000.

When the genotype means of the four trials for grain yield and 100 grain weight are considered, a positive correlation is verified at $5 \%$, with a coefficient of correlation of 0.81 , in agreement with data obtained by Camargo \& Oliveira (1983) and Camargo (1987a; b). The coefficient of correlation obtained indicated a tendency for the most productive genotypes to yield the heaviest grains.

Table 4 - One hundred grain weight, of genotypes assessed in theDihaploid Wheat Lines Trial in Monte Alegre do Sul and in Tatuí, during 1999 and 2000.

\begin{tabular}{|c|c|c|c|c|c|c|c|}
\hline \multirow{2}{*}{ Genotype } & \multicolumn{3}{|c|}{ Monte Alegre do Sul } & \multicolumn{3}{|c|}{ Tatuí } & \multirow{2}{*}{$\begin{array}{c}\text { General } \\
\text { mean }\end{array}$} \\
\hline & 1999 & 2000 & Mean & 1999 & 2000 & Mean & \\
\hline & ---------- & & & --- $g$---.. & ------- & --------- & ------------. \\
\hline 1 & $4.08 \mathrm{a}-\mathrm{c}$ & $4.02 \mathrm{a}$ & $4.05 \mathrm{ab}$ & $3.97 \mathrm{a}-\mathrm{c}$ & $3.75 b-e$ & 3.86 & $3.95 \mathrm{ab}$ \\
\hline 2 & $3.09 d-f$ & $2.66 \mathrm{c}-\mathrm{g}$ & $2.87 \mathrm{~d}-\mathrm{f}$ & $2.77 \mathrm{f}-\mathrm{i}$ & $3.66 b-e$ & 3.21 & $3.04 b-d$ \\
\hline 3 & $3.44 \mathrm{c}-\mathrm{e}$ & $2.22 \mathrm{e}-\mathrm{g}$ & $2.83 \mathrm{df}$ & $3.20 \mathrm{~d}-\mathrm{h}$ & $3.90 \mathrm{a}-\mathrm{d}$ & 3.55 & $3.19 b-d$ \\
\hline 4 & $3.67 \mathrm{c}-\mathrm{e}$ & $2.51 \mathrm{~d}-\mathrm{g}$ & $3.09 c-f$ & $3.54 b-e$ & $3.82 b-d$ & 3.68 & $3.38 b-d$ \\
\hline 5 & $3.51 \mathrm{c}-\mathrm{e}$ & $2.53 \mathrm{~d}-\mathrm{g}$ & $3.02 \mathrm{~d}-\mathrm{f}$ & $2.60 \mathrm{~g}-\mathrm{i}$ & $3.73 b-e$ & 3.17 & $3.09 b-d$ \\
\hline 6 & $3.70 \mathrm{~cd}$ & $2.77 \mathrm{c}-\mathrm{g}$ & $3.23 b-e$ & $3.49 b-f$ & $3.86 b-d$ & 3.68 & $3.46 \mathrm{a}-\mathrm{c}$ \\
\hline 7 & $4.41 \mathrm{ab}$ & $3.51 \mathrm{a}-\mathrm{c}$ & $3.96 \mathrm{a}-\mathrm{c}$ & $4.38 \mathrm{a}$ & $2.68 \mathrm{f}-\mathrm{h}$ & 3.53 & $3.74 \mathrm{ab}$ \\
\hline 8 & $4.71 \mathrm{a}$ & $3.92 a b$ & $4.32 \mathrm{a}$ & $4.51 \mathrm{a}$ & $4.76 \mathrm{a}$ & 4.63 & $4.48 \mathrm{a}$ \\
\hline 9 & $3.60 \mathrm{c}-\mathrm{e}$ & $2.91 c-f$ & $3.25 b-e$ & $3.97 \mathrm{a}-\mathrm{c}$ & $3.07 \mathrm{~d}-\mathrm{g}$ & 3.52 & $3.39 \mathrm{a}-\mathrm{d}$ \\
\hline 10 & $3.82 \mathrm{bc}$ & $2.88 c-f$ & $3.35 b-e$ & $3.80 \mathrm{a}-\mathrm{d}$ & $2.40 \mathrm{gh}$ & 3.10 & $3.22 b-d$ \\
\hline 11 & $2.98 \mathrm{ef}$ & $2.95 c-f$ & $2.96 \mathrm{~d}-\mathrm{f}$ & $2.87 e-i$ & $3.91 \mathrm{a}-\mathrm{d}$ & 3.39 & $3.18 b-d$ \\
\hline 12 & $3.88 \mathrm{bc}$ & $3.04 \mathrm{c}-\mathrm{e}$ & $3.46 \mathrm{a}-\mathrm{d}$ & $4.18 a b$ & $3.46 b-f$ & 3.82 & $3.64 \mathrm{a}-\mathrm{c}$ \\
\hline 13 & $3.00 \mathrm{ef}$ & $2.13 \mathrm{fg}$ & 2.57 ef & $2.23 \mathrm{i}$ & $1.90 \mathrm{~h}$ & 2.07 & $2.32 \mathrm{~d}$ \\
\hline 14 & $3.94 \mathrm{bc}$ & $3.33 \mathrm{a}-\mathrm{d}$ & 3.64 a-d & $3.63 b-e$ & $4.04 \mathrm{a}-\mathrm{c}$ & 3.83 & $3.74 a b$ \\
\hline 15 & $4.01 b c$ & $3.15 a-d$ & $3.58 \mathrm{a}-\mathrm{d}$ & $3.53 \mathrm{~b}-\mathrm{e}$ & $4.26 \mathrm{ab}$ & 3.89 & $3.74 a b$ \\
\hline 16 & $2.68 \mathrm{f}$ & $1.92 \mathrm{~g}$ & $2.30 \mathrm{f}$ & $2.98 e-i$ & $2.91 \mathrm{e}-\mathrm{g}$ & 2.95 & $2.62 \mathrm{~cd}$ \\
\hline 17 & $3.86 b c$ & $2.95 c-f$ & $3.41 \mathrm{~b}-\mathrm{e}$ & $3.31 \mathrm{c}-\mathrm{g}$ & $3.44 b-f$ & 3.38 & $3.39 \mathrm{a}-\mathrm{d}$ \\
\hline 18 & $3.72 b-d$ & $3.15 \mathrm{a}-\mathrm{d}$ & $3.43 b-e$ & $2.51 \mathrm{hi}$ & $3.98 a-c$ & 3.25 & $3.34 b-d$ \\
\hline 19 & $3.65 \mathrm{c}-\mathrm{e}$ & $2.92 c-f$ & $3.28 b-e$ & $3.96 \mathrm{a}-\mathrm{c}$ & $3.35 c-f$ & 3.66 & $3.47 a-c$ \\
\hline 20 & $3.87 \mathrm{bc}$ & $3.35 a-d$ & $3.61 \mathrm{a}-\mathrm{d}$ & $3.89 a-d$ & $3.56 b-f$ & 3.72 & $3.67 \mathrm{a}-\mathrm{c}$ \\
\hline$F($ Gen.) & $13.32^{*}$ & $10.75^{*}$ & $10.08^{*}$ & $19.91^{*}$ & $15.11^{*}$ & 1.40 & $4.91^{*}$ \\
\hline F (Years) & - & - & $114.36^{*}$ & - & - & 0.09 & - \\
\hline F (Trials) & - & - & - & - & - & - & $11.74^{*}$ \\
\hline$F(G \times Y)$ & - & - & 2.06 & - & - & $14.43^{*}$ & - \\
\hline$F(G \times T)$ & - & - & - & - & - & - & $7.30^{*}$ \\
\hline d.m.s. ${ }^{(1)}$ & 0.70 & 0.87 & 0.89 & 0.76 & 0.90 & - & 1.09 \\
\hline C.V. (\%) & 7.22 & 11.23 & 9.19 & 8.32 & 9.70 & 8.99 & 9.09 \\
\hline
\end{tabular}

(1)Means followed by at least one common letter, do not differ among themselves, by Tukey test.

*Significant at $5 \%$. 
The joint analysis for plant height in the trials installed in Monte Alegre do Sul and Tatuí, during 1999 and 2000, indicated, through analysis of variance, significant effects for genotypes, trials, and for the genotype $x$ trial interaction (Table 5), in agreement with results obtained by Camargo et al. (1989; 1990). Despite of the significant genotype $x$ trial interaction, line 13 revealed as one of the shortest in all trials, and it could be utilized in breeding programs as a source for the short plant stature trait. Dihaploid line $13(61 \mathrm{~cm})$ was the shortest, not differing from lines $6(67 \mathrm{~cm}), 7(68 \mathrm{~cm})$ and $10(65 \mathrm{~cm})$. These show a potential for cropping under irrigation conditions, since shorter plants present a reduced tendency to lodging, when compared to high stature plants (Scheeren et al., 1981; Camargo et al., 1999). Genotypes $3(116 \mathrm{~cm})$ and $18(119 \mathrm{~cm})$ were the tallest, not differing from line 2 only $(108 \mathrm{~cm})$.

The analysis of variance of data from the Monte Alegre do Sul trials, during 1999 and 2000, revealed significant effects only for genotypes and for years.
Genotypes $6(68 \mathrm{~cm}), 10(68 \mathrm{~cm})$ and $13(65 \mathrm{~cm})$ were the shortest, not differing from lines 5 and 7 only, at 70 and $73 \mathrm{~cm}$, respectively.

Genotypes 3 and 18 were the tallest, at 119 and $125 \mathrm{~cm}$, respectively, not differing from line $2(112 \mathrm{~cm})$, when the Monte Alegre do Sul trials were analyzed jointly.

Significant effects for genotypes were verified in the Tatuí trials, when analyzed jointly, for years and for the genotypes $x$ years interaction.

When the 1999 and 2000 data are pooled together, line $13(58 \mathrm{~cm})$, which had the shortest plants, did not differ from genotypes 5, 6, 7, 9, 10, 12, 15, 17 and 19, where plant height ranged from 62 to $78 \mathrm{~cm}$; the tallest genotypes, $3(114 \mathrm{~cm})$ and $18(112 \mathrm{~cm})$, only did not differ from lines $2(104 \mathrm{~cm})$ and $4(99 \mathrm{~cm})$. In 1999, line $13(65 \mathrm{~cm})$ was distinguished as having the shortest plants, not differing from lines 6,7 and 10 only $(71,70$ and $69 \mathrm{~cm}$, respectively). Lines 3 and 18 (both at 123 $\mathrm{cm}$ ) were the tallest, not differing, however, from line 2 only $(113 \mathrm{~cm})$. In the year 2000 , line $13(50 \mathrm{~cm})$, which

Table 5 - Plant height of genotypes assessed in the Dihaploid Wheat Lines Trial in Monte Alegre do Sul and in Tatuí, during 1999 and 2000.

\begin{tabular}{|c|c|c|c|c|c|c|c|}
\hline \multirow{2}{*}{ Genotype } & \multicolumn{3}{|c|}{ Monte Alegre do Sul } & \multicolumn{3}{|c|}{ Tatuí } & \multirow{2}{*}{$\begin{array}{c}\text { General } \\
\text { mean }\end{array}$} \\
\hline & 1999 & 2000 & Mean & 1999 & 2000 & Mean & \\
\hline & --------י & - & - n & ------ cm - & - & - & 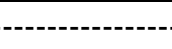 \\
\hline 1 & $96 c d$ & $95 \mathrm{c}$ & $96 \mathrm{c}$ & $96 \mathrm{~cd}$ & $69 \mathrm{~b}-\mathrm{d}$ & $82 \mathrm{c}-\mathrm{e}$ & $89 \mathrm{c}$ \\
\hline 2 & $106 \mathrm{~b}$ & $118 a b$ & $112 a b$ & $113 a b$ & $94 \mathrm{a}$ & $104 a b$ & $108 \mathrm{ab}$ \\
\hline 3 & $119 a$ & $119 a b$ & $119 a$ & $123 a$ & $106 a$ & $114 \mathrm{a}$ & $116 \mathrm{a}$ \\
\hline 4 & $103 b-d$ & $110 a b$ & $107 \mathrm{~b}$ & $104 \mathrm{bc}$ & $94 a$ & $99 a-c$ & $103 \mathrm{~b}$ \\
\hline 5 & $69 \mathrm{ef}$ & $71 \mathrm{de}$ & $70 \mathrm{de}$ & $76 \mathrm{fg}$ & $76 b$ & $76 d-f$ & $73 \mathrm{fg}$ \\
\hline 6 & 68 ef & $69 \mathrm{de}$ & $68 \mathrm{e}$ & $71 \mathrm{gh}$ & $61 c-f$ & 66 ef & $67 \mathrm{gh}$ \\
\hline 7 & 71 ef & $75 \mathrm{de}$ & $73 \mathrm{de}$ & $70 \mathrm{gh}$ & $57 d-f$ & 63 ef & $68 \mathrm{gh}$ \\
\hline 8 & $91 \mathrm{~d}$ & $93 \mathrm{c}$ & $92 \mathrm{c}$ & $90 d$ & $69 b-d$ & $79 c-e$ & $85 \mathrm{~cd}$ \\
\hline 9 & $76 e$ & $79 d$ & $77 d$ & 83 ef & $57 d-f$ & 70 ef & $74 d-g$ \\
\hline 10 & $67 \mathrm{f}$ & $70 \mathrm{de}$ & $68 \mathrm{e}$ & $69 \mathrm{gh}$ & 54 ef & 62 ef & $65 \mathrm{gh}$ \\
\hline 11 & $96 \mathrm{~cd}$ & $95 \mathrm{c}$ & $96 \mathrm{c}$ & $93 \mathrm{de}$ & 72 bc & $82 \mathrm{c}-\mathrm{e}$ & $89 \mathrm{c}$ \\
\hline 12 & $87 d$ & $91 \mathrm{c}$ & $89 \mathrm{c}$ & $87 d$ & $66 \mathrm{~b}-\mathrm{e}$ & $76 d-f$ & $83 c-f$ \\
\hline 13 & $62 \mathrm{f}$ & $68 e$ & $65 e$ & $65 \mathrm{~h}$ & $50 \mathrm{f}$ & $58 \mathrm{f}$ & $61 \mathrm{~h}$ \\
\hline 14 & $92 d$ & $92 \mathrm{c}$ & $92 \mathrm{c}$ & $93 \mathrm{de}$ & $68 b-d$ & $80 \mathrm{c}-\mathrm{e}$ & $86 \mathrm{c}$ \\
\hline 15 & $90 d$ & $91 \mathrm{C}$ & $90 \mathrm{c}$ & $93 \mathrm{de}$ & $64 \mathrm{~b}-\mathrm{e}$ & $78 d-f$ & $84 c-f$ \\
\hline 16 & $96 \mathrm{~cd}$ & $96 \mathrm{c}$ & $96 \mathrm{c}$ & $96 \mathrm{~cd}$ & $74 \mathrm{~b}$ & $85 b-d$ & $90 \mathrm{c}$ \\
\hline 17 & $89 d$ & $92 \mathrm{c}$ & $90 \mathrm{c}$ & $87 d$ & $64 \mathrm{~b}-\mathrm{e}$ & $75 d-f$ & $83 c-f$ \\
\hline 18 & $124 a$ & $127 a$ & $125 a$ & $123 a$ & $101 \mathrm{a}$ & $112 \mathrm{a}$ & $119 a$ \\
\hline 19 & $95 \mathrm{~cd}$ & $97 \mathrm{c}$ & $96 \mathrm{c}$ & $92 d$ & $65 b-e$ & $78 \mathrm{~d}-\mathrm{f}$ & $87 c$ \\
\hline 20 & $90 \mathrm{~d}$ & $93 \mathrm{c}$ & $92 \mathrm{c}$ & $92 d$ & $66 \mathrm{~b}-\mathrm{e}$ & $79 c-e$ & $85 \mathrm{~cd}$ \\
\hline F (Gen.) & $75.77^{*}$ & $61.24^{*}$ & $120.93^{*}$ & $66.45^{*}$ & $38.35^{*}$ & $18.17^{*}$ & $51.85^{*}$ \\
\hline F (Years) & - & - & $16.32^{*}$ & - & - & $142.52^{*}$ & - \\
\hline F (Trials) & - & - & - & - & - & - & $96.37^{*}$ \\
\hline$F(G \times Y)$ & - & - & 0.99 & - & - & $4.70^{*}$ & - \\
\hline$F(G \times T)$ & - & - & - & - & - & - & $3.80^{*}$ \\
\hline d.m.s. ${ }^{(1)}$ & 10 & 11 & 9 & 11 & 13 & 21 & 12 \\
\hline C.V. (\%) & 4.33 & 4.72 & 4.80 & 4.45 & 7.05 & 5.89 & 5.32 \\
\hline
\end{tabular}

(1)Means followed by at least one common letter, do not differ among themselves, by Tukey test.

*Significant at $5 \%$. 
did not differ from lines 6, 7, 9 and $10(61,57,57$ and $54 \mathrm{~cm}$, respectively) having the shortest plants, while genotypes $2(94 \mathrm{~cm}), 3(106 \mathrm{~cm}), 4(94 \mathrm{~cm})$ and $18(101$ $\mathrm{cm})$ had the tallest plants.

The correlation between grain yield and plant height, when the genotypes means obtained in trials at Monte Alegre do Sul and Tatuí, during both years, were considered, did not show significant effects; this indicated that the tallest genotypes did not tend to be the most productive, contradicting Camargo \& Oliveira (1983), which found a coefficient of correlation with positive and significant values.

Genotypes 5, 10 and 13, exhibiting mean plant heights of 73, 65 and $61 \mathrm{~cm}$, respectively, showed resistance to lodging (Table 6). Lines 6, 7, 12 and 20, with lodging percentage means ranging from 4 to $9 \%$ were considered as moderately resistant to lodging; the remaining genotypes, with lodging percentages ranging from 15 to $45 \%$ were considered as susceptible to lodging.

A tendency was verified, according to which taller plants have a greater lodging percentage, and shorter plants a greater resistance, and this fact was confirmed by the positive coefficient of correlation $\left(r=0,79^{*}\right)$ between genotype means for plant height and lodging, obtained for the four trials.

According to the scale proposed by Mehta (1978), lines 3, 4, 5, 8, 16 and 18, with a infection degree means ranging from 1 to $5 \%$, were considered as resistant to the causal agent of leaf rust, representing sources of resistance to this disease, and could be utilized in breeding programs (Table 6). Lines 1, 2, 6, 7, $9,10,11,12,14$ and 17, and cultivars IAC-24 and IAC289 , with a infection degree means, between 6 and 25\%, were moderately resistant, according to the same scale.

When evaluated in nutrient solution in the absence of aluminum, all genotypes presented normal root growth; the difference observed between root lengths is genetic in origin (Table 6).

In the solution containing 2 and $4 \mathrm{mg} \mathrm{L}^{-1}$, all genotypes presented root growth, and were considered, therefore, as tolerant for this concentration, except for the control cultivar Anahuac (susceptible), for which no root growth was observed. Genotypes 13 and 20 had an irreversible paralyzation of root growth after growing for 72 hours in a complete solution, which followed treatment for 48 hours in a solution of 6 and $8 \mathrm{mg} \mathrm{L}^{-1}$ aluminum, therefore being considered as sensitive for this concentration; the other genotypes were tolerant for this concentration, since they had root growth. At the concentration of $10 \mathrm{mg} \mathrm{L}^{-1}$ aluminum, genotype 10 revealed root growth paralyzation. This genotype, plus lines 13 and 20, were considered as sensitive for this concentration; the other were considered as tolerant. The results obtained in nutrient solution suggest that all

Table 6 - Percentage of lodging and degrees ${ }^{(1)}$ of infection by leaf rust (LR) means in the trials installed in Monte Alegre do Sul and in during 1999 and 2000 , and mean length $(\mathrm{mm})$ of roots of genotypes assessed for aluminum toxicity ${ }^{(2)}$.

\begin{tabular}{|c|c|c|c|c|c|c|c|c|}
\hline \multirow{2}{*}{ Genotype } & \multirow{2}{*}{ Lodging } & \multirow{2}{*}{ LR } & \multicolumn{6}{|c|}{ Aluminum concentration $\left(\mathrm{mg} \mathrm{L}^{-1}\right)$} \\
\hline & & & 0 & 2 & 4 & 6 & 8 & 10 \\
\hline & $\%$ & & 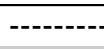 & $2---\cdot-$ & 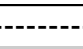 & 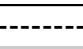 & ------- & -------- \\
\hline 1 & 39 & $13 \mathrm{~S}$ & 58.8 & 28.0 & 10.9 & 0.8 & 0.2 & 0.2 \\
\hline 2 & 31 & $6 S$ & 62.3 & 40.4 & 11.9 & 5.5 & 2.5 & 0.1 \\
\hline 3 & 45 & tS & 56.7 & 49.4 & 30.0 & 22.2 & 10.9 & 4.1 \\
\hline 4 & 19 & $2 S$ & 60.0 & 48.4 & 30.9 & 23.3 & 8.9 & 0.7 \\
\hline 5 & 0 & $3 S$ & 61.0 & 40.8 & 34.9 & 10.3 & 4.3 & 0.5 \\
\hline 6 & 9 & $11 S$ & 51.5 & 40.3 & 31.2 & 20.1 & 14.0 & 9.8 \\
\hline 7 & 4 & $11 \mathrm{~S}$ & 52.2 & 46.6 & 27.8 & 6.3 & 1.4 & 1.0 \\
\hline 8 & 19 & $5 S$ & 61.8 & 46.1 & 41.1 & 36.2 & 20.9 & 14.2 \\
\hline 9 & 18 & $11 \mathrm{~S}$ & 56.7 & 41.8 & 28.6 & 10.8 & 5.6 & 0.9 \\
\hline 10 & 0 & $8 S$ & 49.4 & 31.7 & 15.3 & 5.4 & 1.1 & 0.0 \\
\hline 11 & 23 & $20 S$ & 53.3 & 46.8 & 37.9 & 31.3 & 20.9 & 12.3 \\
\hline 12 & 9 & $8 S$ & 56.4 & 48.2 & 38.5 & 30.6 & 21.4 & 16.7 \\
\hline 13 & 0 & $37 \mathrm{~S}$ & 51.5 & 3.5 & 0.7 & 0.0 & 0.0 & 0.0 \\
\hline 14 & 21 & $15 S$ & 60.7 & 49.2 & 34.9 & 24.3 & 18.0 & 13.8 \\
\hline 15 & 23 & $28 \mathrm{~S}$ & 61.1 & 41.7 & 22.6 & 12.3 & 3.9 & 3.2 \\
\hline 16 & 38 & $4 S$ & 55.8 & 41.6 & 31.0 & 23.1 & 12.7 & 6.4 \\
\hline 17 & 15 & $14 S$ & 55.7 & 40.1 & 31.3 & 20.1 & 12.1 & 10.1 \\
\hline 18 & 31 & $5 S$ & 59.2 & 55.9 & 47.4 & 39.6 & 22.7 & 18.7 \\
\hline 19 & 25 & $9 S$ & 56.8 & 48.6 & 44.5 & 31.4 & 15.4 & 10.8 \\
\hline 20 & 6 & $18 S$ & 62.1 & 30.7 & 4.7 & 0.0 & 0.0 & 0.0 \\
\hline $\mathrm{BH}-1146$ & & & 90.2 & 74.7 & 57.8 & 45.9 & 24.8 & 19.7 \\
\hline Anahuac & & & 62.9 & 0.0 & 0.0 & 0.0 & 0.0 & 0.0 \\
\hline
\end{tabular}

${ }^{(1)}$ Evaluation of leaf rust according to Schramm et. al. (1974).

(2) Mean length $(\mathrm{mm})$ of roots, after growing for 72 hours in a complete solution, which followed growth in a treatment solution containing three different aluminum concentrations (mean of five replicates). 
genotypes, except lines 10,13 and 20 , could be sown under dry land conditions and in very acid soil with a high aluminum content aiming at an economic production.

\section{CONCLUSIONS}

Anther culture was demonstrated as a useful breeding technique, allowing breeders to obtain lines that bear desirable agronomic traits, providing savings in time and resources, as compared to other traditional methods.

Line 8, resulting from the ANA/IAC-24 cross, presented high grain yield, semi-dwarf size, heavy grains, leaf rust resistance and tolerance to aluminum toxicity.

Lines $4,8,11,12$ and 14 had high tolerance to toxicity by aluminum associated to a yield higher than $3.000 \mathrm{~kg} \mathrm{ha}^{-1}$, and therefore can be utilized in wheat breeding programs for obtaining cultivars in soils of high acidity.

\section{REFERENCES}

BRAMMER, S.P.; FERNANDES, M.I.B. de M.; MINELLA, E.; ARIAS; G.; SÓ e SILVA, M.; IORCZESKI, E.J.; SILVA, A.L.S.; PANDOLFI, V. Haplodiploidização e identificação de genótipos de cevada com capacidade androgenética no programa de melhoramento da Embrapa trigo. In: REUNIÃO NACIONAL DE PESQUISA DE TRIGO, 8., Passo Fundo, 1999. Anais. Passo Fundo: Embrapa Trigo, 1999. p.188-192

CAMARGO, C.E.O. Melhoramento do trigo. XIII. Estimativas de variância, herdabilidade e correlações em cruzamentos de trigo para produção de grãos e tolerância à toxicidade de alumínio. Bragantia, v.46, p.73-89, $1987 a$

CAMARGO, C.E.O. Melhoramento do trigo. XIV. Correlações entre a tolerância à toxicidade a dois níveis de alumínio e altura das plantas com outros caracteres agronômicos em trigo. Bragantia, v.46, p.91-103, 1987b.

CAMARGO, C.E.O.; OLIVEIRA, O.F. de Tolerância de cultivares de trigo a diferentes níveis de alumínio em solução nutritiva e no solo. Bragantia, v. 40, p. 21-31, 1981.

CAMARGO, C.E.O.; OLIVEIRA, O.F. Melhoramento do trigo: V. Estimativas da herdabilidade e correlações entre altura, produção de grãos e outros caracteres agronômicos em trigo. Bragantia, v.42, p.131-148, 1983.

CAMARGO, C.E.O.; FELÍCIO, J.C.; FERREIRA FILHO, A.W.P. Variedades de trigo para o Estado de São Paulo. Campinas: Instituto Agronômico, 1996. 20p. (Boletim Técnico, 167)

CAMARGO, C.E.O.; FERREIRA FILHO, A.W.P.; FREITAS, J.G. Avaliação de genótipos de centeio, triticale, trigo comum e trigo duro quanto à tolerância ao alumínio em solução nutritiva. Scientia Agricola, v.55, p.227232, 1998
CAMARGO, C.E.O.; FELÍCIO, J.C.; FERREIRA FILHO, A.W.P.; BARROS, B.C.; FREITAS, J.G.; SANTOS, R.R.; SABINO, J.C. Melhoramento do trigo: XII. Comportamento de linhagens originárias de trigos de inverno $e$ de primavera no Estado de São Paulo. Bragantia, v.48, p.173-203, 1989

CAMARGO, C.E.O; FELÍCIO, J.C; FERREIRA FILHO, A.W.P ; FREITAS, J.G.; BARROS, B.C.; CASTRO, J.L.; SABINO, J.C.; KANTHACK, R.A.D. Melhoramento do trigo. XXIII. Avaliação de linhagens na região do vale do Paranapanema, em Capão Bonito e Tietê, em 1984-88. Bragantia, v.49, p.43-67, 1990

CAMARGO, C.E.O.; FELÍCIO, J.C.; FERREIRA FILHO, A.W.P.; BARROS B.C.; FREITAS, J.G.; PETINELLI JR., A.; GALLO, P.B.; KANTHACK, R.A Melhoramento do trigo: XXV. Avaliação de genótipos oriundos de populações híbridas introduzidas de Oregon (E.U.A.) no Estado de São Paulo. Bragantia, v.50, p.225-246, 1991.

CAMARGO, C.E.O.; RAMOS, L.C.S.; FERREIRA FILHO, A.W.P.; FELÍCIO J.C.; PETTINELLI JR., A.; CASTRO, J.L.; YOKOO, E.Y. Linhagens diaplóides de trigo: produção de grãos, características agronômicas e tolerância à toxicidade de alumínio. Bragantia, v.58, p.235-246, 1999.

FELÍCIO, J.C.; CAMARGO, C.E.O.; VITTI P.; CAMPAGNOLLI, D.M.F. Comportamento agronômico e avaliação tecnológica dos cultivares de trigo IAC-120 (Curumi), IAC-286 (Takaoka) e IAC-289 (Marruá) para o Estado de São Paulo. Bragantia, v.53, p.191-208, 1994.

INDICADORES DA AGROPECUÁRIA. Brasília: Companhia Nacional de Abastecimento - CONAB, v.10, n. 2, 2001, p.12, 46

MEHTA, Y.R. Doenças do trigo e seu controle. São Paulo: Agronômica Ceres, 1978. 190p. (Ceres, 20).

MORAES-FERNANDES, M.I.B. Perspectivas da biotecnologia para o melhoramento de plantas. Pesquisa Agropecuária Brasileira, v.22, p.881-896, 1997

MOTA, F.S. Clima e zoneamento para a triticultura no Brasil. In: FUNDAÇÃO CARGILL. Trigo no Brasil. Campinas, 1982. v. 2, p.29-64

RAIJ, B. van; SILVA, N.M.; BATAGLIA, O.C.; QUAGGIO, J.A.; HIROCE, R.; CANTARELLA, H.; BELINAZZI JR., R.; DECHEN, A.R.; TRANI, P.E. Recomendações de adubação e calagem para o Estado de São Paulo Campinas: Instituto Agronômico, 1985. 107p. (Boletim Técnico, 100).

RAMOS, L.C.S.; CAMARGO, C.E.O.; FERREIRA FILHO, A.W.P.; YOKOO, E.Y.; CASTRO, J.L.; PETTINELLI JR., A.; SILVA, M.R. da. Melhoramento do trigo: avaliação de linhagens diaplóides obtidas via cultura de anteras. Scientia Agricola, v.57, p.177-183, 2000.

REUNIÃO da Comissão Técnica de Trigo da Secretaria de Agricultura e Abastecimento do Estado de São Paulo: Variedades de trigo para o Estado de São Paulo. Campinas, 1996. 20 p. (IAC. Boletim Técnico, 163)

SCHEEREN, P.L.; CARVALHO, F.I.F.; FEDERIZZI, L.C. Componentes da estatura de planta em trigo. Pesquisa Agropecuária Brasileira, v.16, p.527-538, 1981

SCHRAMM, W: FULCO, W.S.; SOARES, M.H.G; ALMEIDA, A.M.P. Resistência de cultivares de trigo em experimentação ou cultivo no Rio Grande do Sul, às principais doenças fúngicas. Agronomia Sulriograndense, v.10, p.31-52, 1974.

TOMASINI, R.G.A. Evolução histórica e aspectos econômicos. In: FUNDAÇÃO CARGILL. Trigo no Brasil. Campinas, 1982. v.1, cap.1, p.3-25, 1982.

Received December 12, 2001 